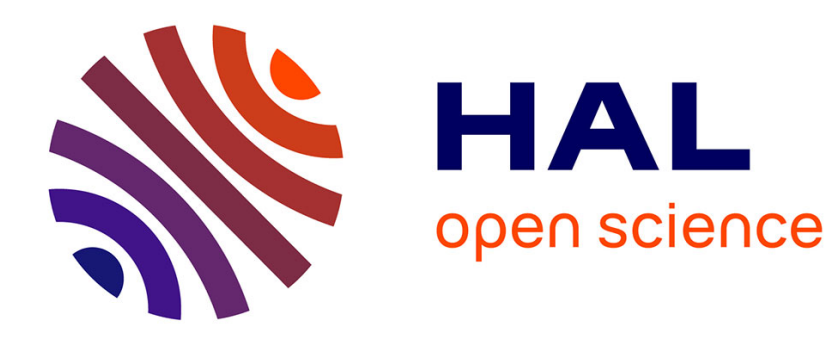

\title{
Snoek Peaks of Carbon in Fe-Ni Meteorites
}

M. Weller, C. Wert

\section{To cite this version:}

M. Weller, C. Wert. Snoek Peaks of Carbon in Fe-Ni Meteorites. Journal de Physique IV Proceedings, 1996, 06 (C8), pp.C8-131-C8-134. 10.1051/jp4:1996826 . jpa-00254634

\section{HAL Id: jpa-00254634 https://hal.science/jpa-00254634}

Submitted on 1 Jan 1996

HAL is a multi-disciplinary open access archive for the deposit and dissemination of scientific research documents, whether they are published or not. The documents may come from teaching and research institutions in France or abroad, or from public or private research centers.
L'archive ouverte pluridisciplinaire HAL, est destinée au dépôt et à la diffusion de documents scientifiques de niveau recherche, publiés ou non, émanant des établissements d'enseignement et de recherche français ou étrangers, des laboratoires publics ou privés. 


\title{
Snoek Peaks of Carbon in Fe-Ni Meteorites
}

\author{
M. Weller and C. Wert* \\ Max-Planck-Institut für Metallforschung, Institut für Werkstoffwissenschaft, Seestrasse 92, \\ 70174 Stuttgart, Germany \\ * Department of Materials Science and Engineering, University of Illinois, Urbana, IL 61801, U.S.A.
}

\begin{abstract}
Most Fe-Ni meteorites are a two phase mixture of fcc and bcc phases. We secured six samples of Fe contents from $95 \%$ to $85 \%$ all of which were thought to contain small amounts of carbon. We found no Snoek peaks in the as-received condition for any of the six. After being heated and cooled, three showed pronounced Snoek peaks, three showed no Snoek peaks.
\end{abstract}

\section{INTRODUCTION}

Solid matter occupying the volume of the solar system ranges in size from the sun and the planets to submicroscopic dust. The planets, of course, have sun-centered orbits. Smaller objects, asteroids and meteoroites also have sun-centered orbits, some of which intersect the orbit of the earth - such particles may eventually fall into the earth's atmosphere. Particles (of size up to a few grams) burn up upon entry because of frictional heating of the earth's atmosphere, but some larger objects survive to fall to the earth. These are called meteorites - about 100 per year of size larger than 500 grams fall on land. Of these, only a few are recovered; the total number of known - and named - meteorites is fewer than 10.000 . General features of the meteorites may be found in the books of Wasson [1] and Dodd [2].

Most meteorites are mixtures of mineral constituents - called stony meteorites. Some $5 \%$ are ironnickel alloys - called irons. Others are mixtures, given names which depend on the metallic and mineral content. Since meteorites are composed of ordinary minerals, metallic alloys and included gases, they are amenable to study by usual techniques of physics and chemistry, as well as by the many techniques of materials science. This paper reports the use of internal friction Snoek-effect to examine the carbon concentration in the bcc phase of several iron-based meteorites.

\section{NATURE OF METEORITES}

Study of radioactive decay products of stony meteorites fixes the age of the solar system at $4.53 \mathrm{Gyr}$, with an uncertainty of about 0.02 Gyr [3]. Also, they formed within a relatively short time, a period less than 16 Myr. Thus the time period of formation of the meteorites is nearly a $\delta$-function about a time $4.53 \mathrm{Gyr}$ ago. The chemical composition of the stony meteorites is about the composition of the nebular gas cloud at the time they were formed - thus, on average, about that of the chemical composition of the sun.

Agglomeration of the solid particles by heating and collisions has altered the microstructure of the original solids. Because of differences in initial local composition and in later agglomeration, about a dozen distinct classes of stony meteorites have been named. Aggregation by collisions and concomitant heating of some objects permitted reduction of iron-nickel compounds to metallic alloys. When accretation of matter was sufficient, small planets formed in which the metallic alloys melted and sank to their centers, as has occured in the earth. Later cooling allowed these cores to solidify and collisions with other bodies formed fragments which we call the iron-nickel meteorites. Some $5 \%$ of the finds are composed of these alloys. Their composition is typically from 90 to $95 \%$ iron, with traces of other metallic impurities.

Cooling of the molten iron-nickel alloys took place slowly, since the overlying mineral mantle had low thermal conductivity. Cooling rates in the solid form are estimated to be from one to several hundred 
$\mathrm{K}$ per million years. Thus the resultant phase mixtures are nearly in thermodynamic equilibrium, as given by the Fe-Ni phase diagram [4], sketched in Figure 1. The composition of several of our samples is indicated in this figure. The first phase which forms is an fcc phase called taenite. Because of the slow cooling rate, the crystal size can be large - $\gamma$-phase single crystals more than 1 meter in size are often observed. Upon further cooling a bcc phase richer in iron precipitates (it is called kamacite). For meteorites of the higher Ni concentrations, this phase precipitates as plates on the octahedral planes of the fcc taenite. The resultant pattern is called the Widmanstätten structure [5] (after the Austrian Count von Widmanstätten, who observed it in the early 1800's). An example of this pattern for one of our samples is shown in Figure 2.

The width of the kamacite bands (or their absence for certain compositions) varies among the meteorites. This variation is related to variations in the $\mathrm{Fe} / \mathrm{Ni}$ ratio, as well as to variation in cooling rates. Some 15 classes of the iron meteorites have been named. We have secured and made measurements on six samples covering a wide range of compositions. We secured these samples from Mr. Blaine Reed of Durango, Colorado, collector and seller of meteorites. Pertinent features are listed in Table 1.

Table 1: Properties of Meteorites

\begin{tabular}{|c|c|c|c|c|c|c|}
\hline Name & Site & olass: & Besiglation & $\mathbf{N}(\%)$ & \multicolumn{2}{|c|}{ Putwor (WLPTM) } \\
\hline W| & 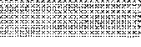 & & & & Wenture & Shok Red \\
\hline Tres Castillos & Mexico & IIIAB & Octahedrite & - & - & 4 \\
\hline Sikhote-Alin & Siberia & IIB & Octahedrite & 5.9 & 170 & 5 \\
\hline Gibeon & Namibia & IVA & Octahedrite & 7.9 & 300 & 1 \\
\hline Chinga & Africa & IVB & Ataxite & 16.6 & 1300 & - \\
\hline Canyon Diablo & SW USA & I & Octahedrite & 7.2 & 1400 & $<1$ \\
\hline Guadalupa y Calvo & Mexico & IIAB & Hexahedrite & $\sim 4$ & - & $<1$ \\
\hline
\end{tabular}

The historical and physical features of many iron-meteorites found before 1975 have been published by Buchwald [6]. His compilation includes chemical composition of representative samples: in addition to the nickel content, he also lists trace metal impurities. Small amounts of carbon are always present, usually in the low ppm range. Part of this carbon is thought to be graphite, but some might be present in solid solution in either the taenite or kamacite phase. That part in solution in the bcc phase might be expected to contribute to a Snoek peak. It is this possibility which provided the incentive for the present work.

Heating of a large meteorite by friction during its fall alters the solid only within a few $\mathrm{mm}$ of the surface. Passage through the atmosphere is rapid enough that appreciable heating of the interior does not occur for either the stony or the iron meteorites. Thus the phases present deep within the bulk and their chemical composition are characterisitic of the solid as it existed before entry.

\section{THE MEASUREMENTS}

The materials, as received, were either thin slabs around $30 \times 40 \times 5 \mathrm{~mm}^{3}$ or were larger, irregularly shaped masses. Thin ribbons of size around $5 \mathrm{~mm} \times 25 \mathrm{~mm} \times 0.5 \mathrm{~mm}$ were cut from these materials using standard abrasive cutting blades. They were then mounted in a torsional pendulum fixed to oscillate at around $8 \mathrm{~Hz}$. The internal friction was measured on heating from about $200 \mathrm{~K}$ to $950 \mathrm{~K}$. No heat treatments were given to the specimens before this measurement.

None of the specimens showed a Snoek peak upon first measurement. However, three of the specimens showed a Snoek peak on a second measurement, after being cooled in the apparatus from $950 \mathrm{~K}$. Two of the three, Sikhote-Alin and Tres Castillos, showed a pronounced peak, Figures 3a and $3 \mathrm{~b}$. Repeated measurements for both showed the peak to be reproducible and stable. The third specimen, Gibeon, showed a small peak at the same temperature, Figure 3c.

These peaks occur at the correct temperature for the Snoek peak of carbon in iron. The carbon is apparently not in solid solution in the as-found state, but is put into solution upon heating. That the peak is found at the correct temperature for carbon in pure iron is consistent with earlier observations that Ni does not alter the peak position for carbon, as it does for nitrogen. The peaks also have the correct width; they are not broadened. The specimens are a mixture of $\alpha$ and $\gamma$ phases of slightly variable spatial $\mathrm{Fe} / \mathrm{Ni}$ 
composition. Also their texture is not known. Consequently, use of the peak height to calculate carbon concentration is uncertain. By using the known ratio of $\mathrm{Q}_{\mathrm{m}}^{-1}=6 \cdot 10^{-5}$ per at.ppm for the carbon Snoek peak in iron [7], we can estimate the carbon concentration in Sikhote-Alin as $5 \mathrm{wt}$ ppm, of Tres Castillos as $4 \mathrm{wt} \mathrm{ppm}$ and of Gibeon as $1 \mathrm{wt} \mathrm{ppm}$. These numbers cannot easily be compared to values reported in Table I. First, values in Table 1 are incomplete. Second, values reported for specific meteorites vary greatly - perhaps the analyses are not reliable; more likely the carbon concentration is variable between specimens.

We had expected to see a large Snoek peak for Canyon Diablo, since it is expected to have a large fraction of its volume as kamacite and has a large carbon concentration. Even more so for Guadalupa y Calvo, a low Ni meteorite of a class called hexahedrite, which should be nearly complete kamacite. Yet no peak was seen for either, for reasons we do not yet know. The absence of a peak for Chinga is not surprising, since it has a much higher Ni content.

\section{References}

[1] Wasson, J.T., Meteorites (Freeman and Company, New York, 1987)

[2] Dodd, R.T., Thunderstones and Shooting Stars (Harvard University Press, Cambridge, MA, 1986).

[3] Kirsten, T., Time and the Solar System, in: The Origin of the Solar System, ed. S.F. Dermott (Wiley, New York, 1978).

[4] Massalski, T., ed., Binary Phase Diagrams (ASM, Materials Park, Ohio,.1986) p. 1086.

[5] Paneth, F.A. The Discovery and Earliest Reproductions of the Widmanstätten Figures, Gehochimica et Cosmochimica Acta 18 (1960) 176-182.

[6] Buchwald, V. F., Iron Meteorites, In 3 Vols. (University of California Press, Berkeley,CA, 1975).

[7] Weller, M., Anwendungen der Mechanischen Spektroskopie zur Bestimmung von Fremdatomen in Metallen: in Nichtmetalle in Metallen '96, Münster, to be published by DGM, Oberursel.

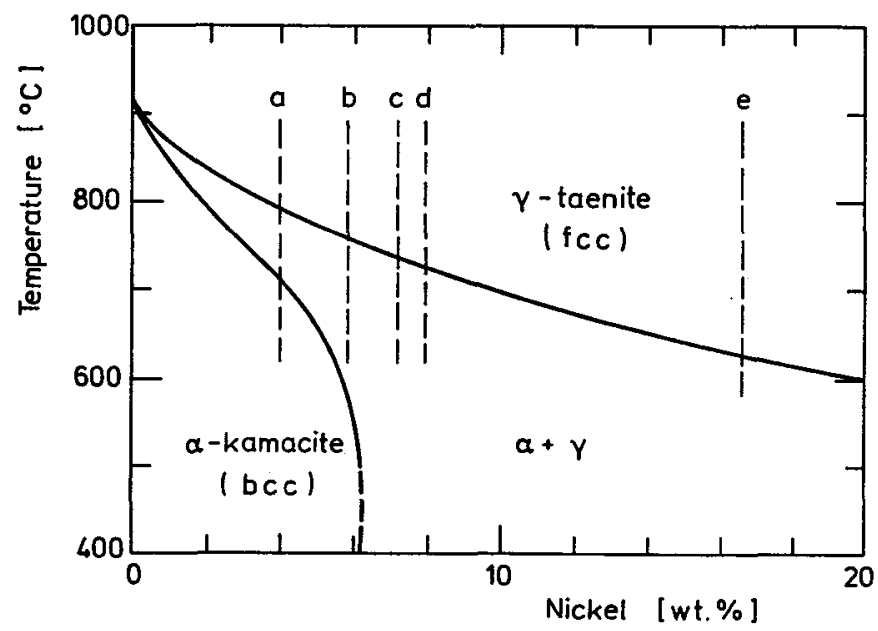

Fig. 1: Low temperature portion of the Fe-Ni phase diagram with various meteorites marked according to their Ni-contents. a ) Guadalupa y Calvo, (b ) Sikhote-Alin, (c) Canyon Diablo, (d ) Gibeon, (e ) Chinga. 


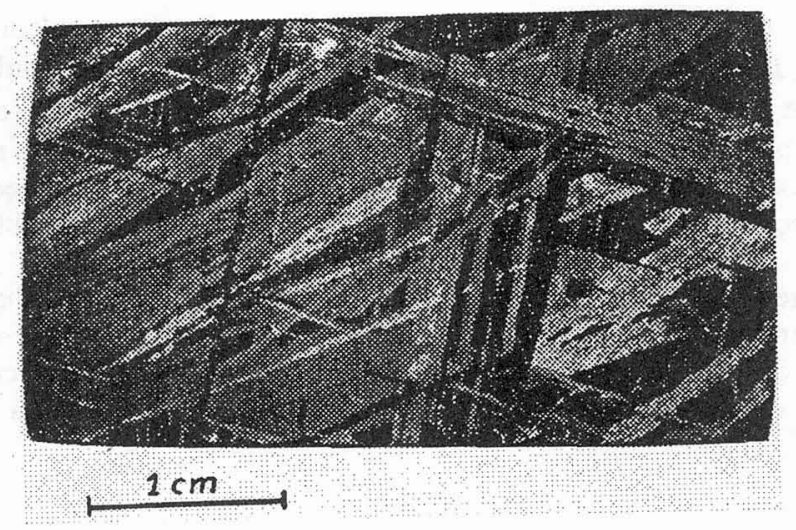

Fig. 2: Widmanstătten structure of meteorite Gibeon.
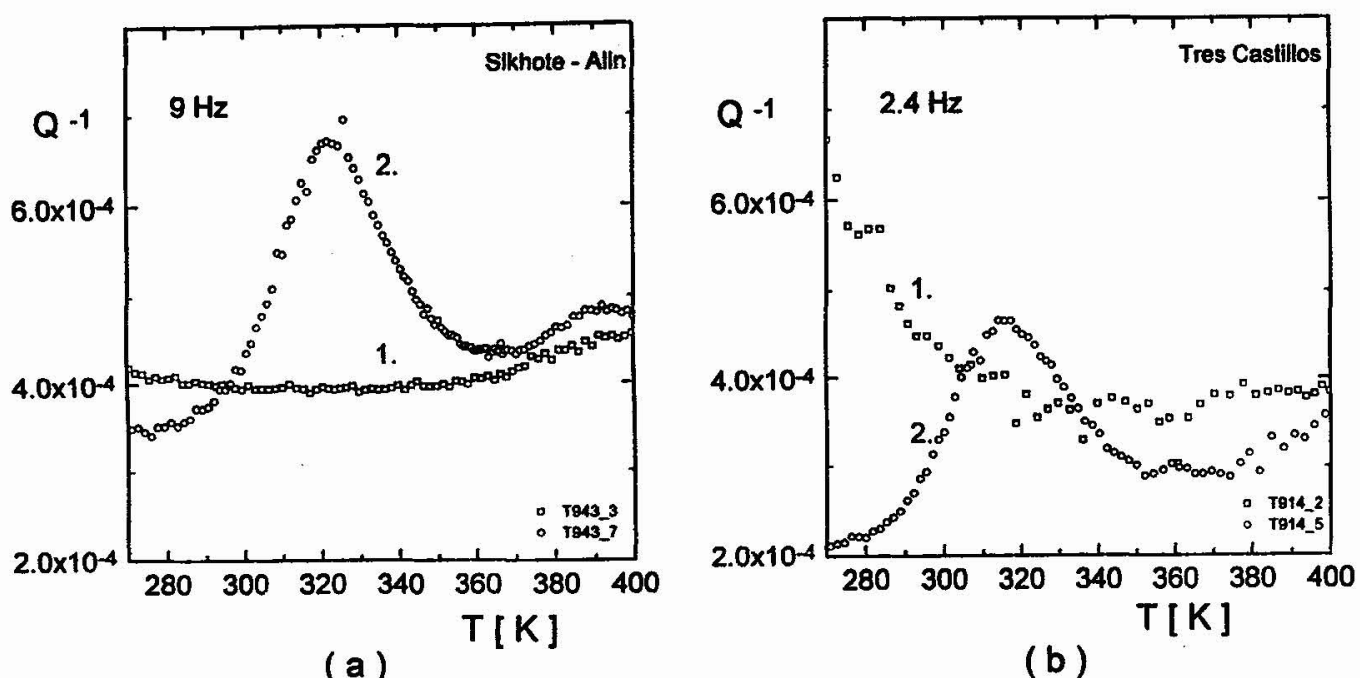

(b)

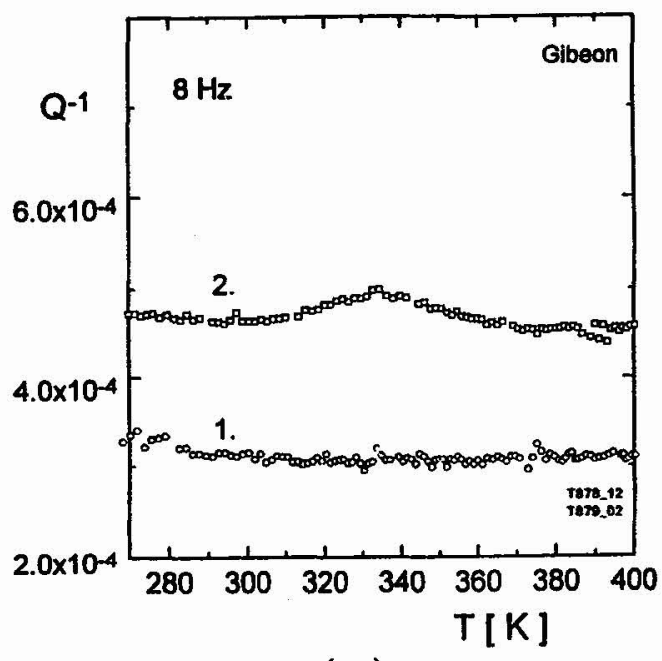

Fig. 3: Internal friction $Q^{-1}$ as a function of temperature for various meteorites.

(a) Sikhote Alin. (b) Tres Castillos.

(c) Gibeon..

(1.) as fallen, (2.) after annealing to $950 \mathrm{~K}$. 